\section{PENGARUH MASA PERIKATAN AUDIT, ROTASI AUDIT DAN UKURAN KANTOR AKUNTAN PUBLIK TERHADAP KUALITAS AUDIT}

\author{
Rahmita Dwinesia Paputungan dan David Kaluge \\ Program Studi Akuntansi FEB Universitas Brawijaya \\ J I. MT Haryono No.165, Malang, J awa Timur, Indonesia \\ Email: rahmitadw@gmail.com
}

diterima 11 Desember 2017, direview 2 J anuari 2017 , direvisi 10 Februari 2017 , diterima 4 Maret 2018.

Artikel ini tersedia di website: http:///journal.umm.acid//index.php//rak Doi: $10.22219 /$ jrak.v8i1.29

\begin{abstract}
A B STRACT
The aim of this study is to examine empirically the affect of audit tenure, audit rotation and public accounting firm size towards audit quality. Audit quality is proxied by using a going concern opinion which is an auditor's opinion that explain a going concern of their client's entity in where they do the audit. This study use purposive sampling to determine samples from manufacturing firms listed in Indonesia Stock Exchange for the year 2010-2016, focus study from 2011-2016, with total observations 105 samples from 143 populations. Data analysis techniques that used is in the form of a logistic regression analysis. The result of this study shows that audit tenure and audit rotation has no significant affect towards audit quality meanwhile public accounting firm size significantly affect the audit quality with negative direction.
\end{abstract}

Keywords: audit tenure, audit rotation, going concern opinion, public accounting firm size

\section{PENDAHULUAN}

Terkait dengan adanya kepentingan manajemen dalam melaporkan hasil kegiatan operasional dan posisi keuangan perusahaannya kepada pihak-pihak yang berkepentingan, maka di butuhkan laporan yang berkual itas. Pada dasarnya akan timbul kesenjangan informasi yang disediakan dikarenakan muncul perbedaan kepentingan antara manajemen dan pemakai laporan. Pada akhirnya peran pihak ketiga yang kompeten dan independen dibutuhkan untuk melakukan pemeriksaan pada laporan keuangan (Al-Thuneibat, et al., 2011). Dalam rangka menjamin laporan keuangan yang dipublikasikan oleh perusahaan dapat di percaya ol eh pengguna, biasanya diperlukan pernyataan dari seorang auditor dimana auditor merupakan pihak ketiga yang objektif dan tepat yang melakukan pemeriksaan independen yang memberikan kredibilitas pernyataan laporan keuangan pada pengguna (Enofe, et al., 2013).

Menurut Arens, et al. (2008) auditor menerima fee dari manajemen perusahaan dalam mel akukan audit. $\mathrm{H}$ al itu berarti, auditor bekerja atas permintaan manajemen. Auditor harus tetap memiliki kebebasan yang cukup untuk melakukan audit sesuai dengan standar yang berlaku guna memenuhi kepentingan pihak ketiga. Dalam hal ini, independensi harus tetap dimiliki setiap akuntan publik sesuai dengan aturan standar umum audit yang kedua, bahwa dalam semua hal yang berhubungan dengan perikatan, independensi dalam sikap mental harus dipertahankan auditor (Agoes, 2012).

Menurut DeAngelo (1981), kualitas audit sebagai sebuah kemungkinan bahwa auditor akan mendeteksi dan melaporkan salah saji material. Proses pelaporan yang dilakukan oleh auditor tergantung kepada dorongan auditor untuk mengungkapkan pelanggaran tersebut. Dorongan ini akan tergantung pada inde-

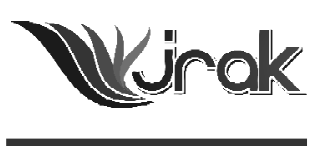

Jurnal Reviu Akuntansi dan Keuangan

p-ISSN : 2615-2223 e-ISSN : 2088-0685 Vol. 8 No. 1, April 2018 Pp 93-103 


\section{Pengaruh \\ Masa \\ Perikatan \\ Audit...}

94

pendensi yang dimiliki auditor tersebut.

Masalah independensi pernah menjadi alasan runtuhnya Kantor Akuntan Publik (KAP) Arthur Anderson pada tahun 2001. Di Indonesia, terjadi kasus manipulasi laporan keuangan pada PT. KAI tahun 2005 yang melibatkan KAP "S. Mannan, Sofwan, Adnan dan Rekan". Kasus tersebut menyebabkan pembekuan izin selama 10 bulan terhadap Akuntan Publik Drs. S. Mannan, yang merupakan pemimpin rekan pada KAP S. Mannan, Sofwan, Adnan dan rekan, sesuai Keputusan Menteri Keuangan Nomor 500/KM.1/2007 tanggal $6 \mathrm{~J} \mathrm{uli} 2007$ (Mahmudah, 2009). Kasus-kasus tersebut menyalahi Standar Profesi Akuntan Publik dalam standar umum kedua (SA 220) yang berbunyi "Dalam semua hal yang berkaitan dengan penugasan, independensi dalam sikap mental harus dipertahankan oleh auditor".

Kasus-kasus yang telah terungkap tersebut juga berdampak dengan dirubahnya KMK N omor 423/K MK.06/2002 menjadi PMK N omor 17/PMK.01/2008. Di dalam Pasal 3 ayat (1) dalam peraturan baru tersebut diatur mengenai tenure dan rotasi audit, yaitu pemberian jasa audit umum atas laporan keuangan dilakukan ol eh KAP paling lama 6 (enam) tahun buku berturut-turut dan ol eh seorang akuntan publik paling lama untuk 3 (tiga) tahun buku berturut-turut. Peraturan tersebut diharapkan mampu meningkatkan kualitas audit di Indonesia dengan mempertahankan independensi auditor.

Faktor lain yang dapat mempengaruhi kual itas audit adalah ukuran Kantor Akuntan Publik (KAP). Kantor Akuntan Publik sendiri merupakan kantor yang menyediakan jasa audit atas laporan keuangan ataupun sebagai kantor untuk jasa konsultasi. Menurut DeAngelo (1981), kualitas audit dari akuntan publik dapat dilihat dari ukuran KAP yang mel akukan audit. KAP sendiri dibagi menjadi 3 tingkatan yaitu first tier, second tier dan third tier dilihat dari sumber daya yang dimiliki KAP tersebut.

Dalam hal ini, KAP besar (The Big 4) diyakini dapat melakukan audit yang lebih berkualitas dibanding dengan KAP kecil (Non-Big 4). KAP Big Four memiliki profitabilitas tinggi, professional staff yang banyak dan pengalaman yang mentereng dalam melakukan audit perusahaan-perusahaan besar termasuk di Indonesia (Christiawan, 2014). Ukuran KAP yang besar menjelaskan kemampuan auditor untuk bersikap independen dan profesional terhadap klien karena mereka kurang bergantung dengan klien (Panjaitan, 2014).

Teori keagenan J ensen \& Meckling (1976, p. 308) menyatakan bahwa adanya pendelegasian tugas dan pengambilan keputusan dan wewenang dari principal ke agent. Agent sebagai pengelola berhak memberikan laporan pada agent terkait pekerjaan yang ia lakukan. Untuk hal tersebut, guna tidak terjadi pembungkaman informasi yang dilakukan oleh agent, di utuslah auditor sebagai upaya untuk mengungkapkan pekerjaan agent dalam usaha milik principal. Hasil pengungkapan tersebut diberikan dalam bentuk opini atas kewajaran laporan keuangan untuk menilai keandalannya agar dapat mengunkur kualitas laporan agent tersebut (Panjaitan, 2014).

Sikap independen audit diperlukan dalam melakukan audit. M enurut Agoes (2012, pp. 34-35) si kap independen harus meliputi independen dalam fakta maupun penampilan, integritas dan objektivitas. Artinya dalam menjalankan tugasnya, KAP atau anggota KAP yang melakukan audit harus mempertahankan sikap integritas dan objektivitas, bebas dari berbagai benturan kepentingan (conflict of interest) dan tidak memperbol ehkan salah saji material (material misstatement) yang diketahuinya atau mengalihkan (mensubordinasikan) perkembangan kepada pihak lain.

DeAngel o (1981) menyatakan bahwa kualitas audit adalah probabilitas gabungan nilai pasar bahwa yang di berikan auditor yaitu menemukan pelanggaran dalam laporan keuangan dan melaporkan pelanggaran tersebut. Kualitas audit merupakan kecenderungan seorang auditor untuk mendeteksi adanya kecurangan 
atau fraud dalam laporan keuangan klien (Febriyanti \& Mertha, 2014).

Going concern sebagai opini merupakan pendapat auditor atas keraguannya pada perusahaan, yakni pada kemampuan perusahaan untuk terus berlangsung. PSA No.30Seksi 341 membahas mengenai "Pertimbangan Auditor atas Kemampuan Entitas dalam M empertahankan Kelangsungan Hidupnya". Paragraf 2 dari PSA tersebut menyebutkan: "Auditor bertanggung jawab untuk mengevaluasi apakah terdapat kesangsian besar terhadap kemampuan entitas dalam mempertahankan kel angsungan hidupnya dalam periode waktu pantas, tidak lebih dari satu tahun sejak tanggal laporan keuangan yang sedang diaudit".

Arens et al . (2008) menyatakan bahwa faktor-faktor yang menimbulkan ketidakpastian mengenai kemampuan perusahaan untuk terus bertahan antara lain:

1) Kerugian operasi atau kekurangan modal kerja yang berulang dan signifikan.

2) Ketidakmampuan perusahaan untuk membayar kewajibannya ketika jatuh tempo.

3) Kehilangan pelanggan utama, terjadi bencana yang tak dijamin ol eh asuransi seperti gempa bumi atau banjir, atau masalah ketenagakerjaan yang tidak biasa.

4) Pengadilan, perundang-undangan, atau hal-hal serupa lainnya yang sudah terjadi dan dapat membahayakan kemampuan entitas untuk beroperasi

Masa perikatan adalah masa perikatan (keterlibatan) antara Kantor Akuntan Publik (KAP) dan klien terkait jasa audit yang disepakati atau dapat juga diartikan sebagai jangka waktu hubungan auditor dan klien (Sinaga, 2012). Masa perikatan sering dikaitkan dengan independensi. Menurut Al-Thuneibat et al. (2011), hubungan yang panjang antara KAP dan klien berpotensi untuk menimbulkan kedekatan antara mereka, hal tersebut dapat menghalangi independensi auditor dan mengurangi kualitas audit.

Rotasi audit bertujuan untuk meningkatkan independensi KAP baik secara tampilan maupun fakta. Proses audit yang berkualitas sangatlah penting untuk menghasilkan informasi akuntansi yang berkualitas yang sangat relevan bagi para pengguna laporan keuangan. Menurut Christiawan (2002) mengatakan kualitas audit ditentukan ol eh dua hal yaitu, kompetensi dan independensi. Rotasi audit akan membuka pintu bagi auditor baru untuk menyelidiki klien dengan pengawasan yang lebih baik dan hati-hati (Al-Thuneibat at el., 2011).

Menurut Peraturan Menteri Keuangan Nomor: 17/PMK.01/2008 tentang jasa akuntan publik menyatakan bahwa Kantor Akuntan Publik yang selanjutnya disebut KAP, adalah badan usaha yang telah mendapatkan izin dari Menteri sebagai wadah bagi Akuntan Publik dalam memberikan jasanya.

DeAngel o (1981) menyatakan bahwa KAP yang memiliki jumlah klien yang lebih banyak memiliki insentif yang lebih besar terhadap kual itas audit. Dari segi ketergantungan ekonomi, KAP besar yang memiliki level kerja yang mendalam dengan para pelanggannya kurang bergantung pada klien tertentu (Choi, et al., 2010). Portofolio yang banyak dari klien yang mereka dapatkan memberikan mereka kemampuan untuk menolak atau menahan tekanan dari klien (DeAngelo, 1981).

KAP besar akan lebih banyak menerbitkan opini going concern di pengaruhi ol eh kemampuan auditor dalam membaca kondisi perusahaan pada saat sekarang maupun untuk masa mendatang. Kemampuan auditor tersebut tersebut akan terasah mengikuti bertambahnya pengalaman melakukan audit (Nindita \& Siregar, 2012). Berdasarkan data dari Departemen Keuangan tahun 2014 tercatat ada 388 KAP di Indonesia dengan bentuk usaha persekutuan berjumlah 201 dan perseorangan berjumlah 187 perusahaan. J umlah tenaga kerja per tahun 2013 sebesar 12.533 orang, dimana tenaga kerja profesi onal auditornya berjumlah 9.177 


\section{Pengaruh \\ Masa \\ Perikatan \\ Audit...}

96 orang atau sebesar $73,22 \%$.

Untuk mengukur besar atau kecilnya sebuah KAP, Adityasih (2010) mengel ompokan KAP Indonesia berdasarkan jumlah auditornya yaitu KAP BIG 4, KAP Menengah, dan KAP Kecil, yaitu:

a. KAP Big 4 (KAP First Tier)

Kelompok ini adalah KAP yang mempunyai jumlah professional staff diatas 400 orang yang terdiri dari PricewaterhouseCooper (PwC), Deloitte, Ernst \& Young dan KPMG. KAP tersebut adalah KAP asing yang berkerjasama dengan KAP Indonesia berupa network maupun asosiasi.

b. KAP Menengah (KAP Second Tier)

Kelompok ini adalah KAP yang mempunyai jumlah professional staff antara 100-400 orang.

c. KAP Kecil (KAP ThirdTier)

Kel ompok ini adalah KAP yang mempunyai jumlah professional staff dibawah 100 orang.

Al-Thunei bat et al. (2011) dalam penel itiannya menemukan bahwa panjang hubungan antara auditor dan klien secara negatif berpengaruh ter hadap kualitas audit sesuai dengan perusahaan manufaktur yang terdaftar di J ordania. Siregar, et al. (2012) dalam penelitiannya menemukan bukti bahwa masa perikatan audit (audit tenure) yang lama dapat mempengaruhi rendahnya kualitas audit sebelum rotasi mandatory auditor diterapkan, sebaliknya setelah rotasi mandatory auditor diterapkan masa perikatan audit yang lama meningkatkan kualitas audit.

$\mathrm{H}$ 1: Masa perikatan berpengaruh terhadap kualitas audit

Untuk mencegah "hubungan yang nyaman" yang akan berakibat pada independensi auditor, maka perlu diadakan rotasi audit. Penganjuran atas rotasi audit dipercaya bahwa skema dari rotasi wajib audit akan mencegah auditor untuk terlalu dekat dengan manajer, yang berdampak terhadap independensi mereka (J ackson, et al., 2008). Dalam penelitiannya menggunakan proxy opini going concern mendapatkan hasil yang signifikan ketika terjadi rotasi terhadap kualitas audit, yakni rotasi positif. Sedangkan Siregar et al. (2012) dalam penelitiannya menyi mpulkan bahwa rotasi auditor sebel um peraturan (rotasi sukarela) meningkatkan kualitas audit sedangkan rotasi mandat tidak memiliki pengaruh yang positif terhadap kualitas audit. $\mathrm{Hal}$ ini mungkin dapat terjadi karena masih lemahnya penegakkan hukum di Indonesia dan adanya celah dalam peraturan rotasi yang memungkinkan firma KAP melakukan rotasi kuasi.

H2: Rotasi audit berpengaruh terhadap kualitas audit

Francis \& Yu. (2009) dalam penelitiannya membuktikan bahwa KAP Big 4 yang berukuran besar mampu menghasilkan kualitas audit yang lebih baik dibandingkan KAP Non-Big 4 yang berukuran kecil. Mereka berargumen bahwa hanya KAP Big 4 yang akan menghasilkan kualitas audit yang tinggi dengan menunjukkan kemampuannya dalam membatasi perilaku manajemen laba dan menerbitkan laporan audit going concern. Penelitian Choi et al . (2010) juga membuktikan bahwa ukuran KAP merupakan faktor yang mempengaruhi kualitas audit karena secara ekonomi mereka kurang bergantung pada klien dan KAP besar mampu membatasi tekanan klien dalam pelaporan yang tidak memenuhi standar atau yang menyimpang. 


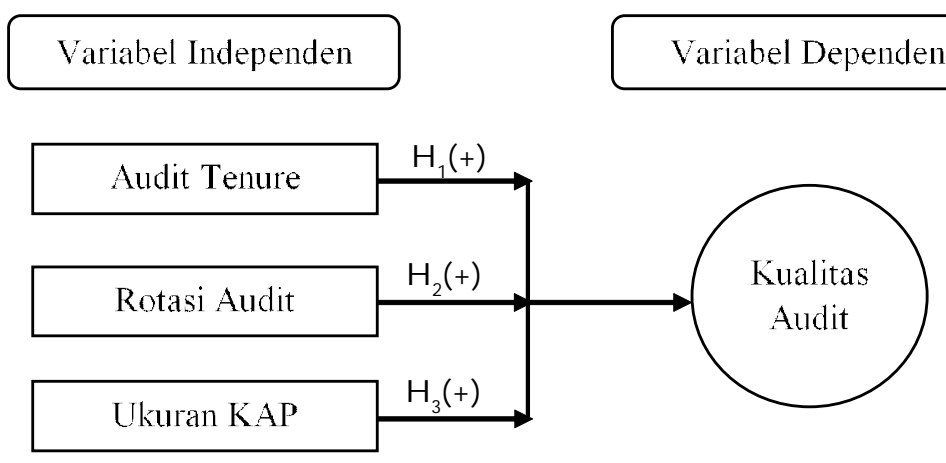

H3: Ukuran KAP berpengaruh terhadap kualitas Audit

Penelitian ini bertujuan untuk menguji secara empiris pengaruh masa perikatan, rotasi audit dan ukuran kantor akuntan publik berpengaruh terhadap kualitas audit. Penelitian ini merupakan penelitian baru dalam tahun yang digunakan dan masa penelitian yang berbeda yang menghasilkan hasil yang berbeda dan bervariasi.

\section{METODE}

Penelitian ini merupakan penelitian empiris yang mana dalam penelitian ini populasi meliputi perusahaan manufaktur yang terdaftar di Bursa E fek Indonesia (BEI) sel ama periode 2010-2016. Adapun pemi lihan sampel untuk penelitian menggunakan metode purposive sampling yang mana sampel yang digunakan berdasarkan kriteria-kriteria yang ditentukan peneliti. Syaratnya diantaranya yaitu perusahaan yang tidak pindah ke bidang lain, perusahaan yang sudah IPO sebel um tanggal $1 \mathrm{~J}$ anuari 2010 dan tidak delisting sel ama waktu penelitian. Terakhir perusahaan dengan data (annual report/laporan keuangan yang telah diaudit) yang telah tersedia secara lengkap di BEI atau website perusahaan selama tahun penelitian. Hasilnya diperoleh sampel sebanyak 105 perusahaan selama setahun dengan fokus penelitian 6 tahun yakni tahun 2011-2016 sehingga fokus sampel penelitian menjadi 630 perusahaan. Variabel rotasi dalam penelitian ini memerlukan data t-1 untuk melihat apakah terjadi rotasi ke tahun dimana penelitian dilakukan.

Data yang digunakan dalam penelitian ini adalah data sekunder yaitu laporan tahunan (annual report) atau laporan keuangan auditan (audited) perusahaanperusahaan manufaktur yang terdaftar di Bursa E fek Indonesia tahun 2010-2016 atau situs BEI yaitu www.idx.co.id, maupun dari website perusahaan.

Penelitian ini menggunakan model penelitian yang terdiri dari 3 variabel independen yaitu masa perikatan audit, rotasi audit dan ukuran KAP dan 1 (satu) variabel dependen yaitu kualitas audit yang diproksikan dengan opini going concern. M etoda analisis yang digunakan yaitu regresi logistik yang mana model nya

$$
\operatorname{Ln} \frac{G C}{1-G C}=\propto+\beta_{1} T A+\beta_{2} R O T+\beta_{3} K A P+\varepsilon
$$

dirumuskan sebagai berikut:

Tenur dan rotasi diukur mengacu pada penelitian Kurniasih (2014), dimana tenure dengan menggunakan skala interval dengan cara menghitung jangka waktu penugasan KAP di suatu perusahaan yang sama (dalam satuan tahun). Tahun pertama perikatan dimulai dengan angka 1 dan ditambah dengan satu 
Pengaruh

Masa

Perikatan

Audit...

98

untuk tahun-tahun berikutnya. Sedangkan rotasi audit diukur dengan menggunakan variabel dummy yaitu nilai 1 jika terjadi rotasi auditor, nilai 0 jika tidak terjadi rotasi auditor. Ukuran KAP diukur dengan menggunakan variabel dummy. J ika perusahaan diaudit oleh KAP Big 4 maka akan diberikan nilai 1. Sedangkan jika perusahaan diaudit oleh KAP non Big 4 maka diberikan nilai 0.

\section{HASIL DAN PEMBAHASAN}

Tabel 1, menunjukkan bahwa seluruh data sampel lengkap untuk masingmasing variabel yakni sebanyak 630 sampel. Berdasarkan tabel, masa perikatan (X1) memiliki mean sebesar 2.81 yang berarti rata-rata perusahaan dalam melakukan masa perikatan adalah sebanyak 2 tahun 8 bulan setelah masa perikatan awal yang terbukti dalam median atau nilai tengahnya yang juga menunjukkan angka 2. Modus (mode) atau nilai yang sering muncul dalam masa perikatan ada sebanyak 1 atau dapat diartikan bahwa perusahaan dalam sampel paling sering memiliki masa perikatan selama 1 tahun. Angka mi nimum masa perikatan adalah 1 tahun dan angka maksimum untuk perikatan yang dilakukan antara KAP dan perusahaan adalah sebanyak 6 tahun.

\begin{tabular}{|c|c|c|c|c|c|}
\hline & & Tenure & Rotasi & U kKAP & OGC \\
\hline \multirow{2}{*}{$N$} & Valid & 630 & 630 & 630 & 630 \\
\hline & Missing & 0 & 0 & 0 & 0 \\
\hline Mean & & 2,808 & 152 & ,421 & ,086 \\
\hline Median & & 2,000 & ,000 & ,000 & ,000 \\
\hline Mode & & 1,0 & ,0 & ,0 & ,0 \\
\hline Minimum & & ,0 & 0 & 0 & 0 \\
\hline Maximum & & 6,0 & 1,0 & 1,0 & 1,0 \\
\hline
\end{tabular}

Tabel 1.

Tabel 2.

Frekuensi Variabel

\begin{tabular}{llcc}
\hline & & Frequency & Valid Percent \\
\hline Tenure & 1 & 184 & 29,2 \\
& 2 & 135 & 21,4 \\
& 3 & 105 & 16,7 \\
& 4 & 83 & 13,2 \\
& 5 & 64 & 10,2 \\
& 6 & 58 & 9,2 \\
Rotasi & Tidak Terjadi Rotasi & 534 & 84,8 \\
& Terjadi Rotasi & 96 & 15,2 \\
UkKAP & KAP Non Big 4 & 365 & 57,9 \\
& KAP Big 4 & 265 & 42,1 \\
& Tidak Menerima Opini Going Concern & 576 & 91,4 \\
& Menerima Opini Going Concern & 54 & 8,6 \\
\hline
\end{tabular}

Rotasi audit (X2) pada seluruh kantor akuntan publik memiliki nilai ratarata sebesar 0.15 yang berarti rata-rata auditor tidak melakukan rotasi dan terlihat pula pada nilai modusnya (mode) bahwa data yang paling sering muncul adalah angka 0 yang merupakan variabel dummy dari tidak terjadi rotasi. Ukuran KAP (X3) memiliki nilai rata-rata sebesar 0.42 yang berarti rata-rata perusahaan yang diaudit oleh KAP Non Big Four sesuai dengan jumlah modusnya yaitu 0 lebih banyak dibanding angka 1 yang merupakan variabel dummy dari KAP Non Big Four. Kualitas Audit (Y) memiliki nilai rata sebesar 0,09 yang berarti banyak perusahaan yang diaudit tidak menerima opini going concern dan hal tersebut 
juga sesuai dengan nilai modusnya yang menunjukkan angka 0 yang merupakan variabel dummy dari tidak menerima opini going concern. Tabel 2 menunjukkan rincian frekuensi pada masing-masing data dimana perikatan sebanyak 1 tahun terjadi pada 184 data dan seterusnya. Data perusahaan sendiri dari 6 tahun, hanya terdapat 96 kali rotasi dan sisanya tidak melakukan rotasi yang sesuai dengan statistic deskriptif dimana perusahaan jarang melakukan rotasi. Ukuran KAP sendiri, lebih banyak perusahaan menggunakan KAP Non Big 4 dibanding KAP Big 4. Selain itu, dari 630 sampel, terjadi 54 laporan keuangan yang menerima opini tentang keberlanjutan usahanya (going concern) sedangkan sisanya tidak menerima opini going concern.

\begin{tabular}{cccc}
\hline Step & Chi-square & df & Sig. \\
\hline 1 & 5,137 & 8 &, 743 \\
\hline
\end{tabular}

Berdasarkan tabel 3, ditunjukkan bahwa nilai dari Hosmer and Lemeshow's Goodness of Fit Test adalah signifikansi sebesar 0.743. Tingkat signifikansi tersebut jauh lebih besar dari 0.05 yang berarti $\mathrm{HO}$ diterima yang berarti bahwa model regresi logistik terhadap data fit. Model mampu memprediksi nilai observasinya atau dapat dikatakan model dapat diterima karena sesuai dengan data observasinya.

\begin{tabular}{cccc}
\hline Iteration & $\mathbf{- 2}$ Log likelihood & $\begin{array}{c}\text { Coefficients } \\
\text { Constant }\end{array}$ \\
\hline \multirow{4}{*}{ Step 0 } & 1 & 398,876 & $-1,657$ \\
& 2 & 369,825 & $-2,211$ \\
& 3 & 368,565 & $-2,358$ \\
& 4 & 368,561 & $-2,367$ \\
\hline
\end{tabular}

Berikut adalah hasil pengujian keseluruhan model:

\begin{tabular}{rrrrrrr}
\hline Iteration & \multicolumn{1}{c}{$\begin{array}{c}\mathbf{2} \mathbf{L} \text { og } \\
\text { likelihood }\end{array}$} & Constant & \multicolumn{2}{c}{ Coefficients } \\
& & Rotasi & UkKAP & Tenure \\
\hline \multirow{6}{*}{ Step 1 } & 1 & 387,275 & $-1,503$ &, 321 &,- 276 &,- 031 \\
& 2 & 348,143 & $-1,857$ &, 561 &,- 654 &,- 078 \\
& 3 & 343,373 & $-1,842$ &, 607 & $-1,012$ &,- 126 \\
& 4 & 343,135 & $-1,808$ &, 595 & $-1,140$ &,- 143 \\
& 5 & 343,134 & $-1,806$ &, 594 & $-1,150$ &,- 144 \\
& 6 & 343,134 & $-1,806$ &, 594 & $-1,150$ &,- 144 \\
\hline
\end{tabular}

Tabel 5. Pengujian Keseluruhan Model (Overall Fit Model) Step 1
Tabel 3. Hosmer and Lemeshow Test

Tabel 4. Pengujian Keseluruhan Model (Overall Fit Model) Step 0
Dari tabel 4. nilai -2 Log Likelihood awal (Block Number $=0$ ) atau sebelum variabel independen dimasukkan ke dalam model sebesar 368,561. Dari tabel 5, nilai -2 Log Likeli hood akhir (Block Number $=1$ ) atau setelah variabel independen dimasukkan ke dalam model sebesar 343,14. Tabel 3 dan tabel 4, nilai -2 Log Likehood awal (Block Number $=0$ ) mengalami penurunan jika dibandingkan dengan -2 Log Likehood akhir (Block Number $=1$ ) yang berarti model fit dengan data atau penambahan 3 variabel independen ke dal am model regresi memperbaiki model fit dan menunjukkan model regresi yang lebih baik. 
Pengaruh

Masa

Perikatan

Audit...

100

Tabel 7. Model

Summary

Tabel 8. Omnibus Tests of Model Coefficients

Tabel 9.

Hasil Pengujian

Model Regresi

\begin{tabular}{cccc}
\hline Step & $\mathbf{- 2}$ Log likelihood & Cox \& Snell R Square & Nagelkerke R Square \\
\hline 1 & $343,134^{a}$ &, 040 &, 089 \\
\hline
\end{tabular}

Tabel 7. di atas menunjukkan bahwa nilai Nagelkerke R Square adalah sebesar 0.089. Hal ini berarti bahwa variabilitas variabel dependen dapat dijelaskan oleh variabilitas variabel-variabel independen sebesar 8,9\%. Dalam pemahaman Iain, berarti bahwa variabilitas variabel masa perikatan, rotasi KAP dan ukuran KAP sebesar $8,9 \%$ sedangkan sisanya sebesar $91,1 \%$ dijel askan ol eh variabel diluar model penelitian.

\begin{tabular}{llccc}
\hline & & Chi-square & df & Sig. \\
\hline \multirow{3}{*}{ Step 1 } & Step & 25,427 & 3 &, 000 \\
& Block & 25,427 & 3 &, 000 \\
& Model & 25,427 & 3 &, 000 \\
\hline
\end{tabular}

Tabel 8. memiliki nilai signifikansi ( $p$-value) 0,000 dimana kurang dari alpha $(\alpha)$ 0,05 sehingga hipotesis pengaruh simultan variabel independen terhadap variabel dependen adalah menerima $\mathrm{H} 1$ atau menolak $\mathrm{H} 0$ yang berarti ada pengaruh signifikan secara simultan masa perikatan, rotasi audit dan ukuran KAP terhadap kualitas audit.

\begin{tabular}{llrrrrrr}
\hline & & B & S.E. & Wald & df & Sig. & Exp(B) \\
\hline \multirow{5}{*}{ Step 1a } & Tenure &,- 144 &, 120 & 1,440 & 1 &, 230 &, 866 \\
& Rotasi &, 594 &, 381 & 2,428 & 1 &, 119 & 1,811 \\
& UkKAP & $-1,150$ &, 386 & 8,884 & 1 &, 003 &, 316 \\
& Constant & $-1,806$ &, 376 & 23,058 & 1 &, 000 &, 164 \\
\hline
\end{tabular}

Dari tingkat signifikansi pada Tabel 9, masa perikatan dan rotasi audit tidak memiliki pengaruh secara signifikan dengan kualitas audit, sedangkan hipotesis yang diajukan adalah masa perikatan dan rotasi audit masing-masing berpengaruh terhadap kualitas audit. $\mathrm{H}$ al tersebut berarti $\mathrm{H} 0$ diterima. Hasil penelitian ini tidak mendukung hasil penelitian Al-Thuneibat (2011), Mgbame, et al. (2012) dan dan Siregar et al.(2012) yang menunjukkan bahwa masa perikatan berpengaruh terhadap kualitas audit. Namun demikian, hasil penelitian ini tidak sejalan dengan penelitian Pratiwi (2013) yakni masa perikatan tidak berpengaruh signifikan terhadap penerimaan opini going concern yang dalam hal ini penerimaan opini tersebut merupakan proksi kualitas audit. Pratiwi (2013) dalam hasil penelitiannya menyimpulkan bahwa hasil penelitiannya memberikan bukti empiris independensi auditor dan objektivitas auditor seiring dengan tenure tidak terganggu dengan lamanya masa perikatan antara klien dan auditor. Hal ini dikarenakan auditor tetap melakukan proses audit sesuai dengan standar yang ada. Penelitian RuizBarbadillo (2009) juga menemukan bahwa rotasi audit secara mandatori tidak memiliki hubungan dengan opini going concern atau juga berarti bahwa tidak terdapat bukti bahwa rotasi mandatori audit mempengaruh pelaporan.

Dari hasil statistik pun menunjukkan bahwa rata-rata masa perikatan antara perusahaan dengan kantor akuntan publik adalah sekitar 2 tahun 1 bulan yang menyatakan perikatan antara perusahaan dengan kantor akuntan publik beserta auditornya cukup singkat. Selain itu terdapat peraturan terbaru yang mengganti PMK Nomor 17/PMK.01/2008 yaitu PP No. 20 Tahun 2015. Dalam pasal 11 Ayat 1 dinyatakan bahwa KAP tidak lagi dibatasi dalam melakukan au- 
dit atas suatu perusahaan. Pembatasan hanya berlaku bagi AP, yaitu selama 5 tahun buku berturut-turut. Selain itu, menurut peneliti, dengan adanya kode etik profesi akuntan publik, mau tidak mau auditor harus mematuhi aturan tersebut yakni mampu menjaga independensi dan keobjektifan dalam melakukan jasa audit sehingga dengan lebih diutamakan kode etik tersebut membuat masa perikatan itu tidak berpengaruh tidak berpengaruh terhadap kualitas audit.

Sedangkan di satu pihak, ukuran KAP berpengaruh secara signifikan terhadap kualitas audit yang mendukung hipotesis yang diajukan pada tingkat signifikansi 5\%. Namun dapat terlihat bahwa arah pengaruh ukuran KAP terhadap kualitas udit menunjukkan arah negatif. Dengan arah negatif tersebut, berarti penelitian ini menunjukkan bahwa KAP Non-Big 4 lebih banyak menerbitkan laporan audit going concern, yang dapat mengindikasi kualitas audit yang berkualitas.

Penelitian yang dilakukan oleh Francis dan Yu (2009) memperol eh ukuran KAP berpengaruh signifikan terhadap kualitas audit yakni dalam penerimaan opini going concern, namun hasil tersebut ditunjukkan dengan arah positif untuk hubungan antara ukuran KAP dan kualitas audit di mana ukuran KAP yang lebih besar menerbitkan laporan audit going concern lebih banyak.

Secara ekonomi KAP besar kurang bergantung pada klien dan KAP besar mampu membatasi tekanan klien dalam pelaporan yang tidak memenuhi standar atau yang menyimpang (Choi et al., 2010). Dengan jumlah klien yang lebih banyak berarti banyak tenaga audit yang professional. Hal tersebut membuat semakin baik kemampuan KAP dalam mendeteksi ketidakmampuan keberlangsungan hidup perusahaan yang diauditnya. Namun bertentangan dengan hal itu, hasil penelitian Nindita \& Siregar (2012) memperoleh hasil negatif dari hubungan ukuran KAP dan kualitas audit. Mereka menyatakan bahwa manajer perusahaan yang rasional tidak akan memilih auditor yang berkualitas tinggi dan membayar fee yang tinggi apabila kondisi perusahaan tidak baik. Hal ini disebabkan karena KAP Big Four yang dianggap berkualitas tinggi akan mampu mendeteksi kondisi perusahaan yang tidak baik dan menyampakainnya ke publik.

$\mathrm{Hal}$ itu berarti, perusahaan biasanya menggunakan KAP besar (Big Four) ketika kondisi perusahaan sedang memiliki kondisi yang baik, sehingga perusahaan tersebut cenderung menerima opini wajar tanpa pengecualian. Sementara perusahaan dengan kondisi perusahaan yang tidak baik, cenderung menggunakan KAP kecil (Non-Big F our) dengan harapan KAP tidak dapat mendeteksi kondisi tersebut.

Dalam hasil ini, banyak perusahaan dalam sampel cenderung menggunakan jasa KAP kecil yakni 365 sampel yaitu 59 perusahaan. Sedangkan perusahaan yang sudah dalam kondisi baik cenderung menggunakan KAP besar dalam mengaudit perusahaannya dibutktikan dengan 265 sampel yang tidak menerima opini going concern yang terdiri dari 46 perusahaan. Selain itu, hanya 11 perusahaan dari 265 sampel yang menerima opini going concern, sedangkan hanya 5 perusahaan yang mendapat opini going concern berturut-turut dari tahun 2011 hingga 2016.

\section{SIMPULAN}

Masa perikatan dan rotasi audit tidak berpengaruh terhadap kualitas audit. $\mathrm{Hal}$ ini disebabkan adanya peraturan pemerintah yang tidak membatasi masa perikatan dan juga rotasi audit terhadap Kantor Akuntan Publik, tapi hanya sebatas pada auditor. Terdapat juga standar auditing dan kode etik yang KAP maupun auditornya harus mematuhi peraturan tersebut, jika tidak ada sanksi yang akan diberikan sesuai UU No. 5 Tahun 2011 pasal 55, sehingga independensi dan objektivitas auditor yang ditunjuk tidak berkurang selama masa perikatan dan tetap. Hal tersebut berarti bahwa auditor/KAP akan tetap melakukan proses au- 
Pengaruh

Masa

Perikatan

Audit...

102 dit sesuai dengan standar auditing hingga menghasilkan opini yang akan mereka berikan untuk perusahaan yang diaudit.

Ukuran KAP berpengaruh signifikan terhadap kualitas audit dengan arah negatif. Perusahaan cenderung tidak menggunakan KAP besar ketika kondisi perusahaan sedang tidak baik karena akan membayar fee yang tinggi dan pada kondisi tersebut akan menggunakan KAP kecil dengan harapan bahwa KAP tersebut tidak dapat mendeteksi kondisi tersebut.

Beberapa keterbatasan dalam penelitian ini adalah dalam menilai kualitas audit yakni hanya dari penerimaan opini going concern, hal tersebut belum menggambarkan kondisi yang sebenarnya, pengukuran dari sisi tenuremasa awal perikatan dilihat pada tahun 2011 sehingga belum menggambarkan masa awal perikatan yang sebenarnya antara perusahaan dan kli en jika dilihat dari tahun sebeI umnya. Varibel independen hanya mengukur dari sisi institusional nya, tidak pada hubungan keagenan ataupun dari sisi internal perusahaan. Pengukuran rotasi audit dan ukuran KAP hanya diukur dengan menggunakan variabel dummy yang belum menggambarkan kondisi audit sebenarnya.

\section{DAFTAR PUSTAKA}

Adityasih, T., 2010. Analisa Pengaruh Pendidikan Profesi, Pengalaman Auditor, J umlah Klien (Audit Capacity) dan Ukuran Kantor Akuntan Publik Terhadap Kualitas Audit. J akarta, Fakultas Ekonomi Universitas Indonesia, Library UI.

Agoes, S., 2012. Auditing (Petunjuk Praktis Pemeriksaan Akuntan ol eh Akuntan Publik). 4 ed. J akarta: Salemba Empat.

Al-Thuneibat, A. A., I brahim, R. T. \& Baker, A. I. R. A. A., 2011. Do Audit Tenure and Firm Size Contribute to Audit Quality?: Empirical Evidencefrom J ordan. Managerial Auditing J ournal, 26(4).

Arens, A. A., Elder, R. J . \& Beasley, M. S., 2008. Auditing dan J asa Assurance. 12 ed. J akarta: E rlangga.

Choi, J .-H., Kim, C. (., Kim, J .-B. \& Zang, Y., 2010. Audit Office Size, Audit Qual ity and Audit Pricing. Auditing: A J ournal of Practice \& Theory, 29(1).

Christiawan, S. I. d. A. T. B... "., 2014. Perbandingan Antara KAP First Tier, KAP Second Tier dan KAP Third Tier dalam Penerbitan Opini Going Concern. EJ ournal UAJ Y.

Christiawan, Y. J ., 2002. Kompetensi dan Independensi Akuntan Publik: Refleksi Hasil Penelitian Empiris. J urnal Akuntansi \& Keuangan, 4(2).

DeAngelo, L. E., 1981. Auditor Size and Audit Quality. J ournal of Accounting and E conomics, 3(3).

Enofe, A. O., M gbame, C. \& Aderin, A., 2013. Determinants of Audit Quality in the Nigerian Business Environment. Research J ournal of Finance and Accounting, 4(4).

Febriyanti, N. M. D. \& Mertha, I. M., 2014. Pengaruh Masa Perikatan Audit, Rotasi KAP, Ukuran Perusahaan Klien dan Ukuran KAP Pada Kualitas Audit. EJ ournal Akuntansi U niversitas U dayana, 7(2).

Francis, J. R. \& Yu., M. D., 2009. The Effect of Big Four Office Size on Audit Quality. The Accounting Review, 84(5).

J ackson, A. B., Moldrich, M. \& Roebuck, P., 2008. Mandatory Audit Firm Rotation and Audit Quality. Managerial Auditing J ournal, 23(5).

J ensen, M. C. \& Meckling, W. H., 1976. Theory of the firm: Managerial behavior, agency costs and ownership structure. J ournal of finance economics, 3(4). 
Mahmudah, N., 2009. I zin Akuntan PT Ker eta Api Dibekukan. [Online]. Available at: www.apauditing.blogspot.co.id [Accessed 11 April 2018].

Mgbame, C. O., Eragbhe, E. \& Osazuwa, N. P., 2012. Audit Partner Tenure and Audit Quality: An Empirical Analysis. European J ournal of Business and Management, 4(7).

Nindita, C. \& Siregar, S. V., 2012. Analisis Pengaruh Ukuran Kantor Akuntan Publik Terhadap Kualitas Audit di I ndonesia. J urnal Akuntansi dan Keuangan, 14(2).

Panjaitan, C. M., 2014. Pengaruh Tenure, Ukuran KAP dan Spesialisasi Auditor terhadap Kualitas Audit. [Online]. Available at: http://eprints.undip.ac.id. [Accessed 11 April 2018].

Pratiwi, K. A., 2013. Pengaruh Audit Tenure, Reputasi KAP, Dislcosure, Ukuran Perusahaan Klien dan Opini Audit Sebelumnya terhadap Opini Audit Going Concern. J akarta, Fakultas Ekonomi dan Bisnis, Universitas Islam Negeri Syarif Hidayatullah.

Ruiz-Barbadillo, E. G.-A. N. a. C. N., 2009. Does Mandatory Audit Firm Rotation EnhanceAuditor Independence? Evidence from Spain. Auditing: A J ournal of Practice \& Theory, 28(1).

Sinaga, D. M. T., 2012. Analisis Pengaruh Audit Tenure, Ukuran KAP dan Ukuran Perusahaan Klien terhadap Kualitas Audit. [Online]. Available at: http:// eprints.undip.ac.id. [Accessed 11 April 2018].

Siregar, S. V., Siregar, S. V., Wibowo, A. \& Anggraita, V., 2012. Audit Tenure, Auditor Rotation, and Audit Quality: The Case of Indonesia. Asian J ournal of Business and Accounting, 5(1). 